\title{
Analysis of the Valuation Activity on Vegetables and Fruits Chains for their Improvement
}

\author{
Valentina Constanta Tudor
}

University of Agronomic Sciences and Veterinary Medicine of Bucharest, 59 Mărăşti Blvd,

District 1, Bucharest, Romania

\begin{abstract}
The cultivation of vegetables and fruit trees was the main activity of the Romanian farms, a country badly affected both by the process of nationalization / collectivization during the communist period and by the defective retrocession of the post-communist period. But since 2007, investments in agriculture, including those in the fruit and vegetables sector, have played an essential role, both by setting up new agricultural holdings and by upgrading the existing ones. During the programming period 2007-2013 and 2014-2020, farmers could access measures that can be plunged into the fruit and vegetable sector. Starting from the main advantages of the fruit and vegetables sector, such as the large assortment of fruit and vegetable species and varieties, the large number of farms, the pedo-climatic conditions favorable to the cultivation of a significant number of varieties, the growing of the areas cultivated with vegetables in protected areas Modernization of the processing units, improving the fruit and vegetable harvesting activity play a particularly important role in the revitalization of this sector. The market for vegetables and fruits is influenced by a number of factors such as: the demand and supply atomicity, product homogeneity, the seasonality of vegetable and fruit products, the high degree of perishability, the demand for vegetables and fruits has a continuous character, the production of vegetables and fruits has different destinations. Modern analysis of the global value chain focuses on actors' relationships as a way to reduce uncertainty, improve access to key resources and increase chain efficiency. For the proper functioning of the vegetable and fruit chain, the producer groups and producer organizations are extremely important.
\end{abstract}

Keywords: Chain, Fruits, Improvement, Vegetables

\section{Introduction}

Over the last 20 years, the Common Agricultural Policy (CAP) has reduced the regulation of agricultural markets, allowing market forces to guide the production. This general approach was specifically applied to the fruit and vegetable sector, whereby instruments such as export refunds or minimum prices that the operators of the processing sector were forced to pay to farmers for certain products (Buda D., 2018). The European Union has associated this liberalization process with a policy of strengthening producer organizations to give farmers the opportunity to act to protect their interests, for example by collectively selling their products or by increasing their value added by their processing at the farm. The CAP therefore provides financial support to producer organizations, which they use to implement "operational programs". Producer organizations use these programs to meet a variety of objectives tailored to their specific situation, such as investing in market campaigns or training activities. The 2007 reform of the fruit and vegetable regime has confirmed and expanded the policy to strengthen the role of producer organizations and associations of producer organizations. In recent years, the EU has increased its funding for operational programs (Nuno M., 2015). Producer organizations are the main actors in the common organization of the market in fruit and 
vegetables, whose role is to concentrate supply and adapt it to market demand, acting in the name and the interests of members. On the other hand, medical and nutritional research has for many years highlighted the health benefits of fruit and vegetable consumption, including the reduction of the occurrence of diseases such as certain cancers, cardiovascular diseases, obesity but also type II diabetes. These foods are low in calories, but rich in nutrients and fiber. According to a study by the World Health Organization in 2013, there were 1.7 million worldwide deaths annually, which were also due to the low consumption of fruits and vegetables that underlie a balanced and healthy diet. Therefore, fruit and vegetable consumption is the main focus of global food interventions by governments as well as by non-governmental organizations (W.H.O., 2018). Studies conducted by Reiss, Johnston, Tucker, Desesso and Keen (2012) show that if at the US level half of the population would consume fruits and vegetables daily, the occurrence of about 20,000 cancer cases could be avoided annually (Reiss R., 2012). In the group analysis sessions led by Uetrecht et. Al in 1999, with parents, employees, health center customers and community members, examined the factors that influence the consumption of fruit and vegetables. They are grouped into three broad categories, namely: related production, distribution channels, and related consumers. Production covers aspects such as price, seasonality, perishability, nutritional content, origin and quality of the product. Seasonality also has a significant influence on availability, variety, taste, quality, freshness, price and the form in which it is purchased, namely, fresh, frozen or preserved (Rekhy R., 2014).

\section{Materials and Methods}

In this study, is presented a documentary synthesis, analysis and interpretation of statistical data collected from the Romanian National Institute of Statistics and also of the official data provided by the Ministry of Agriculture and Rural Development of Romania. Information come also from sources with agricultural statistics and from allowed authors, in order to create a detailed image for the fruit and vegetable sector. The fruit areas and the vegetables areas which are under cultivation are expressed in hectares and the harvested quantity is expressed in thousands tonnes. The data have been processed using the well-known index, share and comparison methods (Popescu A., 2013).

\section{Results and Discussions}

In Romania there has been, for centuries, a strong tradition of family farms. The continuity of this tradition has been interrupted by the process of nationalization and collectivization during the communist era. During this period, traditional farms have been replaced in most areas by government-controlled administrative structures, and the rural population has gradually transformed into state employees, being paid in cash or in cash and in agricultural products. After the fall of communism, the return of nationalized land to former owners began, through a succession of laws whose repercussions felt profoundly on systems of production, post- harvest recovery, infrastructure, research and agricultural consultancy. This has led to dramatic drops in indigenous production levels, but favorable conditions in Romania such as fertile soils, hydrographic network, temperate continental climate have led to the intensive cultivation of vegetables and fruit, developing a whole sector activity in this field (MADR, 2008). In 2008, the Agriculture Ministers of the Member States of the European Union decided to implement a reform for the common organization of the market in the fruit and vegetable sector, starting from the fact that this sector was affected by the existence of a large number of small-scale farms that do not use in modern technical means, the fact that the areas cultivated with trees, fruit trees and vegetables have decreased and that there is a high degree of fragmentation of the areas on which vegetables and fruits are grown, as well as the lack of a coherent land consolidation strategy, the low degree of rejuvenation of the fruit plantations leading to the decline of large areas of fruit plantations but not last but not least the increase in the frequency of extreme climatic phenomena that directly affect production. Taking into account the extremely high potential of this sector in Romania, namely the large number of farms where a vast variety of species and varieties of vegetables and fruits are grown, the increase of the areas on which varieties are grown competitive capacity of fruit trees and vegetables, production capacity in 
the climatic areas of mushrooms, as well as the areas cultivated with vegetables in modern protected areas, but also the possibility of modernizing the processing units, the national strategy for the operational programs in the sector fruit and vegetables for the period 20092013, where a series of common performance indicators have been established to help this sector grow by implementing several types of actions such as (AREFLH, 2016):

- Actions aimed at planning production;

- Actions to improve or maintain product quality;

- Actions aimed at improving marketing;

- Actions on research and experimental production;

- Training actions (other than those related to crisis prevention and management) and promoting access to advice;

- Crisis prevention and management actions and others.

According to the National Statistics Institute of Romania, for the period 2007-2016, the vegetal production in the main crops, the evolution of the surface of vegetables and fruits was decreasing, during the analyzed period, the area cultivated with vegetables decreased by $10 \%$, which represents a decrease with 25 thousand ha, and in the case of the area cultivated with fruit, the decrease was even more pronounced, of 33\% representing 68 thousand hectares. However, total production has grown for both sectors, so vegetable production has increased by around $8 \%$ and production for the fruit sector has increased by just over $14 \%$ (Table 1 ).

Table 1: The evolution of the surface and of the production of fruit and vegetable

\begin{tabular}{|c|c|c|c|c|c|c|c|c|c|c|c|c|}
\hline & UM & $\begin{array}{l}200 \\
7\end{array}$ & $\begin{array}{l}200 \\
8\end{array}$ & $\begin{array}{l}200 \\
9\end{array}$ & $\begin{array}{l}201 \\
0\end{array}$ & $\begin{array}{l}201 \\
1\end{array}$ & $\begin{array}{l}201 \\
2\end{array}$ & $\begin{array}{l}201 \\
3\end{array}$ & $\begin{array}{l}201 \\
4\end{array}$ & $\begin{array}{l}201 \\
5\end{array}$ & $\begin{array}{l}201 \\
6\end{array}$ & $\begin{array}{l}2016 \\
/ \\
200 \\
7\end{array}$ \\
\hline $\begin{array}{l}\text { Surfac } \\
\text { e } \\
\text { fruits }\end{array}$ & $\begin{array}{l}\text { '00 } \\
0 \\
\text { ha }\end{array}$ & $\begin{array}{c}20 \\
6\end{array}$ & 207 & 205 & $\begin{array}{c}19 \\
9\end{array}$ & $\begin{array}{c}14 \\
0\end{array}$ & 142 & 144 & 141 & 139 & $\begin{array}{c}13 \\
8\end{array}$ & $67 \%$ \\
\hline $\begin{array}{l}\text { Produc } \\
\text { tio } n \\
\text { fruits }\end{array}$ & $\begin{array}{l}00 \\
0 \text { to }\end{array}$ & $\begin{array}{c}108 \\
6\end{array}$ & 1179 & 1323 & $\begin{array}{c}142 \\
0\end{array}$ & $\begin{array}{c}148 \\
0\end{array}$ & 1129 & 1300 & 1115 & 1225 & $\begin{array}{c}124 \\
2\end{array}$ & $114 \%$ \\
\hline $\begin{array}{l}\text { Surfac } \\
\text { e } \\
\text { vegeta } \\
\text { ble } \\
\text { S }\end{array}$ & $\begin{array}{l}\text { '00 } \\
0 \\
\text { ha }\end{array}$ & $\begin{array}{c}25 \\
3\end{array}$ & 269 & 267 & $\begin{array}{c}26 \\
3\end{array}$ & $\begin{array}{c}26 \\
3\end{array}$ & 259 & 259 & 239 & 239 & $\begin{array}{c}22 \\
8\end{array}$ & $90 \%$ \\
\hline $\begin{array}{l}\text { Produc } \\
\text { tio n } \\
\text { vegeta } \\
\text { ble } \\
\text { s }\end{array}$ & $\begin{array}{l}100 \\
0 \text { to }\end{array}$ & $\begin{array}{c}311 \\
7\end{array}$ & 3820 & 3902 & $\begin{array}{c}386 \\
4\end{array}$ & $\begin{array}{c}417 \\
6\end{array}$ & 3535 & 3961 & 3803 & 3674 & $\begin{array}{c}335 \\
8\end{array}$ & $108 \%$ \\
\hline
\end{tabular}

Source: Processed after MADR, http://www.madr.ro/horticultura/fructe-si-legume.html.

Another important indicator in the fruit and vegetables sector is the production of vegetables and fruits per capita, and here are the conclusions from the analysis of the data provided by the National Institute of Statistics of Romania:

- In the period 2008-2013, during the appliance of the mentioned strategy, there was an increase of $6,55 \%$ in the production of vegetables per capita and $13,24 \%$ in the fruit production per capita.

- When the period of the application strategy is finished, more exactly in the period 20132016 , it is noticed that the trend of vegetable production per capita is downward, decreasing 
Valentina Constanta Tudor

Analysis of the Valuation Activity on Vegetables and Fruits Chains for their Improvement

by $14.03 \%$, as in the case of of fruit production per capita which decreased by $3.08 \%$ (Chart 1, Table 2).

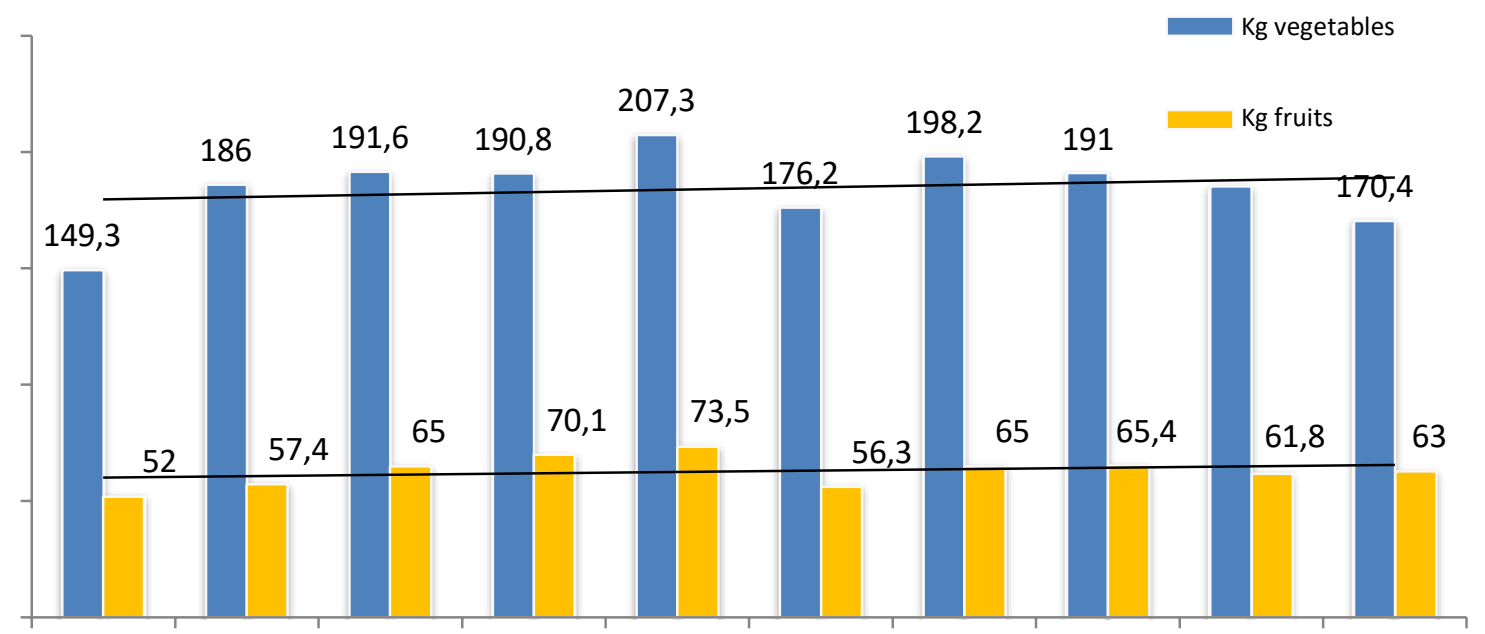

Figure 1: The evolution of production of fruits and vegetables per capita

Table 2: The evolution of production of fruits and vegetables per capita

\begin{tabular}{|l|l|l|l|l|l|l|l|l|l|l|l|l|}
\hline & & $\begin{array}{l}\mathbf{2 0 0} \\
\mathbf{7}\end{array}$ & $\begin{array}{l}\mathbf{2 0 0} \\
\mathbf{8}\end{array}$ & $\begin{array}{l}\mathbf{2 0 0} \\
\mathbf{9}\end{array}$ & $\begin{array}{l}\mathbf{2 0 1} \\
\mathbf{0}\end{array}$ & $\begin{array}{l}\mathbf{2 0 1} \\
\mathbf{1}\end{array}$ & $\begin{array}{l}\mathbf{2 0 1} \\
\mathbf{2}\end{array}$ & $\begin{array}{l}\mathbf{2 0 1} \\
\mathbf{3}\end{array}$ & $\begin{array}{l}\mathbf{2 0 1} \\
\mathbf{4}\end{array}$ & $\begin{array}{l}\mathbf{2 0 1} \\
\mathbf{5}\end{array}$ & $\begin{array}{l}\mathbf{2 0 1} \\
\mathbf{6}\end{array}$ & $\begin{array}{l}\mathbf{2 0 1 6 / 2 0 0} \\
\mathbf{7}\end{array}$ \\
\cline { 1 - 11 } $\begin{array}{l}\text { Vegetab } \\
\text { l es }\end{array}$ & $\mathbf{g}$ & 149 & 186 & 192 & 191 & 207 & 176 & 198 & 191 & 185 & 170 & $114 \%$ \\
\hline Fruits & & 52 & 57 & 65 & 70 & 74 & 56 & 65 & 65 & 62 & 63 & $121 \%$ \\
\cline { 3 - 13 }
\end{tabular}

Source: Processed after INS,

http://statistici.insse.ro/shop/index.jsp?page=tempo3\&lang=ro\&ind=AGR200A

However, with all the efforts of the Ministry of Agriculture and Rural Development to support fruit and vegetable producers, there is a decline in both the total area planted with vegetables and fruits and the total production in this sector (DeCicco, 2016):

- There is a decline in the area planted with vegetables in 2018, which is 268.6 thousand hectares, and at the end of the strategic operational program in the fruit and vegetable sector decreasing by about 3.5\% (in 2013) and also a much more significant decrease in the area under fruit, decreasing by over 30\% in 2013 compared to 2008.

- With regard to total production of vegetables and fruits, we can see that in the case of vegetable production, it increased by 3,69\% from 2008 in 2013, despite the fact that the cultivated area has decreased. The same upward trend is also true for total fruit production, with an increase of $10.23 \%$ from 2008 in 2013.

Here, while the area cultivated with both fruits and vegetables decreased during the period of application of the national strategy for the operational programs in the fruit and vegetables sector, their total production increased, most probably due to the support given to the small producers in order to modernize the processes production and harvesting. However, efforts by local authorities have not been sufficient since between 2013 and 2016, the area planted with vegetables continued its downward trend, decreasing by almost $12 \%$ and the fruit area by just over $4 \%$. Along with the common fruit and vegetable market, it was implemented as mentioned above and the European reform of the fruit and vegetables sector (European Commission, 2018). At present, 24 producer organizations are recognized on the territory of Romania in accordance with EU legislation, and three of them are developing an operational program. The 
main activity of producer organizations refers to both the concentration of supply and the marketing of the products of the members for which they are recognized.

These associative forms sell larger quantities of quality vegetables and fruits, according to current standards, which are currently in the agro-food markets, canteens, wholesale markets and supermarket networks. Although the supply of vegetables and fruit on the territory of Romania is extremely varied, the lack of specialized knowledge in the field of marketing, respectively the methods of preparation of the products resulting from their marketing and the presentation methods leading to attractiveness and safety of the product in the eyes of the consumer, lack of production technology for the purpose of washing, sorting, packaging, labeling, preservation and transport of production to the market, the lack of a production planning system and its articulation according to market requirements and the fact that the added value of the products is extremely small, which leads to instability and notable differences in the producers' incomes lead to increased imports of vegetables and fruits. Chaotic production and inconsistent with market requirements, climatic differences, the occurrence of various diseases and pests, massive imports, poor promotion of the importance of consumption of vegetables and fruit to the health of the population and of vegetables and fruits among consumers, as well as the incomplete and incorrect information submitted by to the media in terms of the fruit and vegetable sector is a part of the factors that generate the crisis of the fruit and vegetable market in Romania. Due to these inconsistencies and the fact that the fruit vegetable sector is declining according to the figures presented by the National Institute of Statistics of Romania, the authorities in the field, namely the Ministry of Agriculture and Rural Development, support the producers of vegetables and fruits with a new national strategy for the operational programs in the fruit and vegetables sector for the period 2018-2020. The objectives of this new strategy are:

- Production planning, including production estimation and monitoring, and a consumption;

- Improving the quality of products, whether they are fresh or processed;

- Increasing the commercial value of products;

- Promotion of fresh or processed products;

- Promoting and providing technical assistance for the use of production, improving product quality;

- Environmental protection measures, especially in the field of water and production methods respecting the environment, including organic farming;

- Management of by-products and waste, especially for quality protection water, soil and landscape and biodiversity conservation or enhancement;

- Crisis prevention and management;

- Crop insurance;

- Ensuring the scheduling and adaptation of production on demand, in particular with regard toquality and quantity;

- Concentrating the offer and placing on the market the products obtained by their members, including through direct marketing;

- Developing initiatives in the field of promotion and marketing;

- Provision of the necessary technical assistance for the use of futures markets;

- Optimizing production costs and return on investment in response to environmental standards and stabilization of production prices;

- Promoting and providing technical assistance for the use of cultivation and production techniques that protect the environment.

- Taking these objectives into account, the activities of the operational programs must be oriented towards the following priorities:

- Increasing the competitiveness of products;

- Optimizing production costs, stabilizing production prices, production and supply planning;

- Promotion;

- Crisis prevention and management;

- Increasing the production potential (MADR, 2018). 


\section{Conclusions}

Romania has a high potential for the production of fruit and vegetables in the field, due mainly to the high natural fertility of soils and the diversity of the climate. The climate and soil of Romania provide favorable conditions for the cultivation of trees and bushes, species spread according to their biological requirements, throughout the country, from the plain to altitudes over $800-1000 \mathrm{~m}$. It is expected that in the next period, the production of vegetables and fruit will increase, but the growth of the sector will be achieved taking into account the pedo-climatic conditions and the needs of the soil, and a sustainable agriculture type. If in the period 20072013 the total fruit and vegetable production increased despite the downward trend of the fruit and vegetable growing area in the period 2013-2016, this descendant is not valid only for the cultivated area but also for the total production of fruit and vegetables vegetables and fruits, with a decline of $15.22 \%$ for vegetables and $4.5 \%$ for fruit.

\section{References}

- AREHLH, (2016), Strategic innovation and research genda for the fruits and vegetable sector, http://euvrin.eu/Portals/476/Final\%20\%20STRATEGIC\%20RESEARCH\%20AND\%20INNOVATION\%20AGENDA\%20FO R\%20THE\%20FRUIT\%20AND\%20VEGETABLE\%20SECTOR\%20v2016\%2021-10-2016.pdf

- Buda D., (2018), Sectorul fructelor și legumelor după 2007, http://www.danielbuda.ro/ro/sectorul-fructelor-si-legumelor-dupa-reforma-din-2007/, Accessed on 12.07.2018;

- DeCicco Antonella, (2016), The fruits and vegetable sector in the EU, https://ec.europa.eu/eurostat/statisticsexplained/index.php/The_fruit_and_vegetable_sector_in_the_EU_-a_statistical_overview, Accesed on 10.07.2018;

- Nuno Melo, (2015), Parlamentul European: Raport referitor la sectorul fructelor și legumelor de la reforma din 2007 și până în prezent, http://www.europarl.europa.eu/sides/getDoc.do?pubRef=-//EP//TEXT+REPORT+A8- 20150170+0+DOC+XML+V0//RO\#top, Accessed on 20.07.2018;

- Popescu A., (2013, ) Considerations on Romania's vegetable market. Scientific Papers. Series "Management, Economic Engineering in Agriculture and rural development", Vol. 13 ISSUE 4, Print ISSN 2284-7995,

- Rekhy Reetica, McConchie R., (2014), Promoting consumption of fruits and vegetables for better health. Have campaigns delivered on the goals?, Appetite, Vol. 79, Elsevier; Crossref

- Reiss R., Johnston J., Tucker K., DeSesso JM., keen CL., (2012), Estimation of cancer risks and benefits associated with a potential increased consumption of fruits and vegetables, Food and Chemical Toxicology, Vol. 50, Issue 12; Crossref

- European Commission, (2018), https://ec.europa.eu/agriculture/fruit-andvegetables/producer-organisations_en, Accesed on 12.07.2018;

- MADR, (2018), Strategia națională pentru programele operaționale în sectorul de fructe și legume, https://ec.europa.eu/agriculture/sites/agriculture/files/fruit-andvegetables/country-files/ro/strategy_ro.pdf, Accessed on 05.07.2018;

- MADR, (2018), http://www.madr.ro/horticultura/fructe-si-legume.html, Accesed on 11.06.2018;

- INS, (2018), Producția principalelor produse agricole, pe locuitor, http://statistici.insse.ro/shop/index.jsp?page=tempo3\&lang=ro\&ind=AGR200A

- World Health Organization, (2018), Promoting fruit and vegetable consumption around the world, http://www.who.int/dietphysicalactivity/fruit/en/, Accessed on 10.06,2018. 